\title{
Development Of Intelligent Decision Support Systems (IDSS) For Optimization Of Fisheries Surveillance Vessel in FMA-711
}

\author{
Hozairi $^{1, a^{*}}$, Marcus Tukan²,b, and Heru Lumaksono ${ }^{3, c}$ \\ ${ }^{1}$ Department of Informatics Engineering, Islamic University of Madura, Pamekasan, Indonesia \\ ${ }^{2}$ Department of Industrial Engineering, University of Pattimura, Ambon, Indonesia \\ ${ }^{3}$ Department of Ship Building Engineering, Shipbuilding Institute of Polytechnic Surabaya, \\ Surabaya, Indonesia \\ a.dr.hozairi@gmail.com,b.mrcustukan@gmail.com,c.heruppns@gmail.com \\ *corresponding author
}

Keywords: IDSS, GA, AHP, FMA-711

Abstract:FMA-711 (Fishery Management Area 711) has an area of 200,216 m2 with operational cost IDR. 1.5 Billion with three main working units (Natuna, Batam and Pontianak). The supervisory model in FMA-711 is still concentrated between the western and eastern regions so that many work units cannot be monitored optimally by the fisheries surveillance vessel. This study aims to develop IDSS (Intelligent Decision Support System) method by combining GA (Genetic Algorithm) and AHP (Analytic Hierarcy Process) method, GA is used to find the optimal solution for assigning fisheries surveillance vessels in each work unit, AHP is used to select candidate solutions generated by GA with consideration of criteria (technical, economic, service, safety and politics). This research has succeeded in finding the optimal solution by combining fisheries surveillance vessels placement in each main work unit. For Natuna recommended type of fisheries surveillance vessel is (B-D-C), coverage area 101.005 Mil2, operating cost IDR.675.1000.982. Pontianak recommended type of fisheries surveillance vessel is (B-E), coverage area 61.016 Mil2, operating expense IDR.396.080.169. Batam recommended type of fisheries surveillance vessel is (D-E), coverage area 47.838 Mil2, operating cost IDR.170.090.284. This research is able to save operational cost $\pm 6 \%$ from total cost prepared by Government of Republic of Indonesia and increase of area supervision up $\pm 15 \%$ from wide area to be secured.

\section{Introduction}

Laws of the republic Indonesia No. 27 of 2007 on the management of coastal areas and small islands is the legitimacy of fishery resources control activities. Supervision and law enforcement in the field of fishery is one of the main duties and functions of the Directorate of Ship Supervisors which is implemented through supervisory boats to conduct marine and fishery resources monitoring operations [1].

In accordance with the main duties and functions of the vessel, the area of operation of the supervisor ship is divided into 2 (two), namely: [a]. Western Region (Malacca Strait, South China 
Sea, Indian Ocean, Mentawai from West Sumatera to South Java), [b] Eastern Region (Indian Ocean, northeast of Flores, sea Banda, sea Arafuru, Maluku sea, Tomini bay, Sulawesi sea and pacific ocean) [1].

The fisheries surveillance vessel is an activity to prevent the acts that deviate or take repressive actions against a violation of the laws and regulations in the field of fisheries.

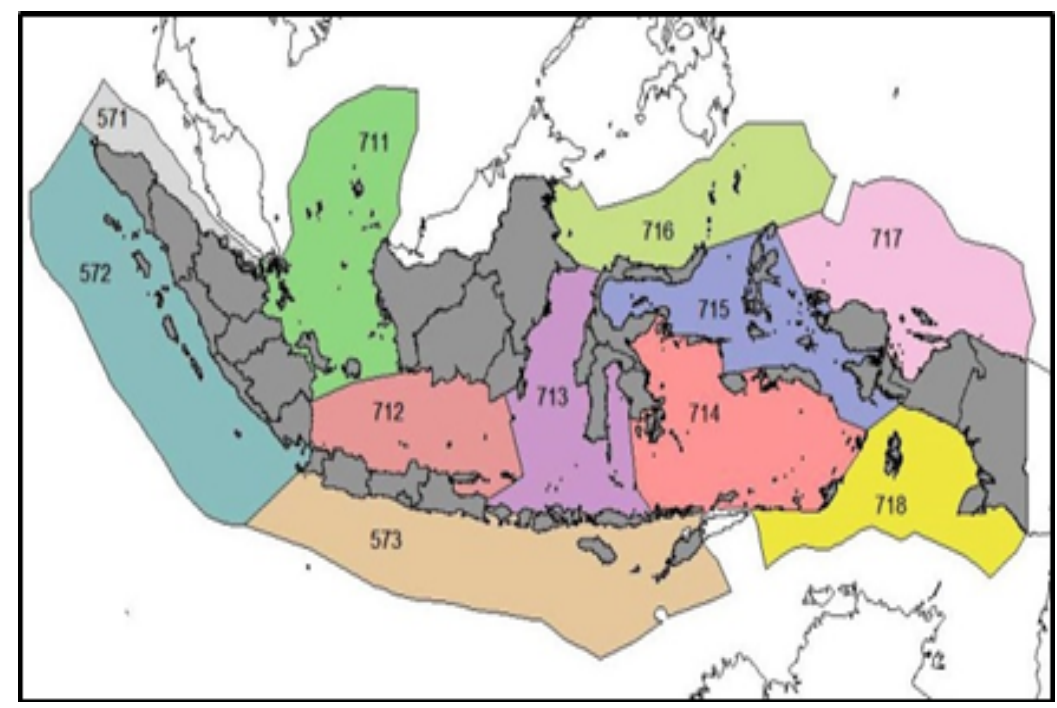

Figure 1: Map of Fisheries Management Area of the Republic of Indonesia

Illegal Fishing activities in FMA-711 have caused huge losses for Indonesia. Overfishing, overcapacity, threats to the sustainability of fish resources, unfavourable fishery business climate, weakening of the competitiveness of firms and the marginalization of fishermen. Another disadvantage that cannot be judged materially but is closely related to the nation's self-esteem is the destruction of Indonesia's good name in International level because it is considered unable to manage fishery resources properly [1][2].

Based on the results of previous research on the selection of the main work unit priorities in FMA711 , this study selected the work unit priority with the aim of the effectiveness of the coordination and supervision model of each satker scattered in the region, the method used is TOPSIS [3], the method is improved AHP-TOPSIS method [4], the method is improved the method used FuzzyTOPSIS [5], the three studies yield the same value that is: Natuna Batam and Pontianak work units.

Following up on his research [3] on optimizing the placement of fisheries surveillance vessel in each of the main work units with limited budgets and supervisory boats owned by the Ministry of Marine Affairs and Fisheries of the Republic of Indonesia. The method developed in his research is using Genetic Algorithm as the optimal search engine solution. The research results recommend three best solution candidates in each of the main work units in Natuna (5 combinations of boats), Batam (three combinations of boats and Pontianak (three ship combinations).

This research will develop intelligent decision support system that is combination of Genetic Algorithm (GA) and Analytic Hierarchy Process (AHP) method. GA is a method that is able to look for possibilities from candidate solutions to obtain an optimal solution for problem solving, GA method is also able to solve problems that are heuristic, for that need a combination of methods to be able to combine quantitative and qualitative problems with the purpose of research results can describe the interests of decision makers [6][7][8]. 
Analytic Hierarchy Process (AHP) is a method that can accommodate qualitative data to be quantitative. AHP is a very powerful method for solving complex problems. AHP has been used in various fields of science, ranging from engineering, economics, social and public policy. A problem will be solved in an organized mind set, so it can be expressed to make effective decisions so that complex issues can be simplified and accelerated decision-making process [9].

Intelligent Decision Support System (IDSS) is actually a process of development between the method of Decision Support System (DSS) and Artificial Intelligent (AI). This method was developed to assist decision makers at different stages of decision making by integrating human modelling and knowledge. This study aims to determine the optimal combination of patrol boats in Natuna, Batam and Pontianak work units using IDSS method [10].

\section{Research Method}

\subsection{Research Process}

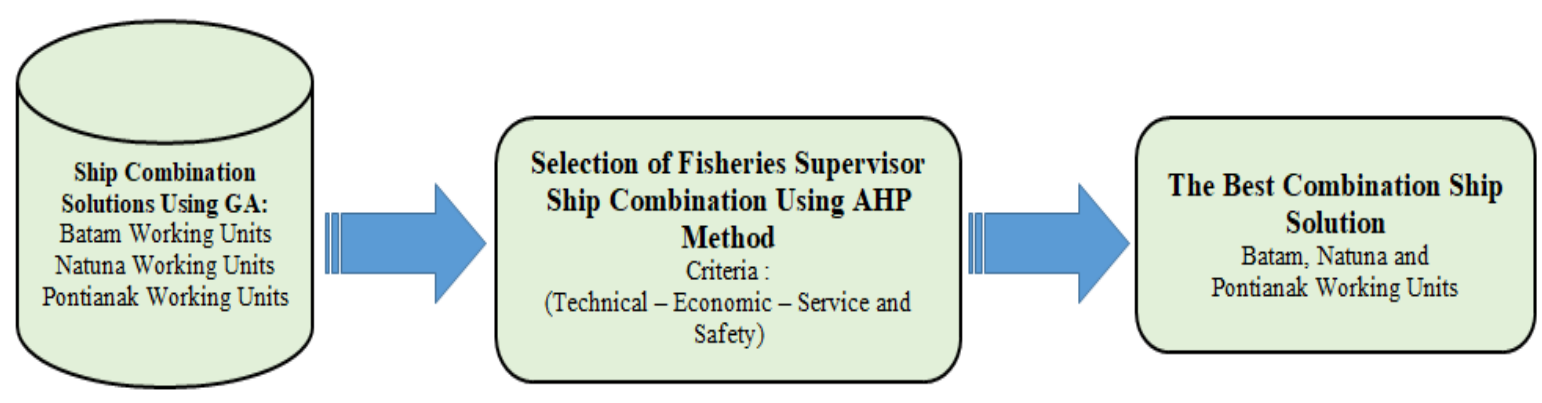

Figure 2: Research stage

This study aims to find the model of supervision of work units (satker) in 711 namely satker Natuna, Batam and Pontianak. The model developed to improve waters control is to arrange the appropriate deployment of fisheries surveillance vessel in accordance with the vulnerability of the area, if the model of supervision is good then the better the level of security of the region.

Stages of the method developed in this study is to combine Genetic Algorithm (GA) with Analytic Hierarchy Process (AHP). The GA method is used to find the best optimal vessel placement solution in several key work units, while the AHP method is used to select the best supervisory model based on the qualitative considerations of the decision maker (Government).

\subsection{Intelligent Decision Support System (IDSS)}

IDSS is a tool to assist the decision-making process in which the uncertainty of a solution becomes a complex issue where the decision should be made using human judgment and its preference. IDSS as an implied concept, is used to support decision making and is not intended to replace the decision maker's task. In addition, IDSS works under the assumption that decision makers are more familiar with the issues to be solved. In this case, IDSS gives users complete control over information acquisition, evaluation and final decision making.

IDSS is an interactive system, flexible, adaptable and specifically developed to support unstructured management problem solving to improve decision making [11]. A more cognitive IDSS than a technological system, the fundamental difference being that the basic characteristics of intelligence cannot be captured in mechanistic [12]. Most researchers agree that the goal of is to support unstructured management solutions and enable the processing of knowledge with better communication skills [13]. 


\subsection{Genetic Algorithm (GA)}

Genetic Algorithm (GA) is a searching algorithm based on work through natural selection mechanism. GA differs from the conventional search algorithm because it starts with an initial set of so-called populations. Each individual in the population is called a chromosome, within a chromosome there are several genes and each gene has a value called the allele.

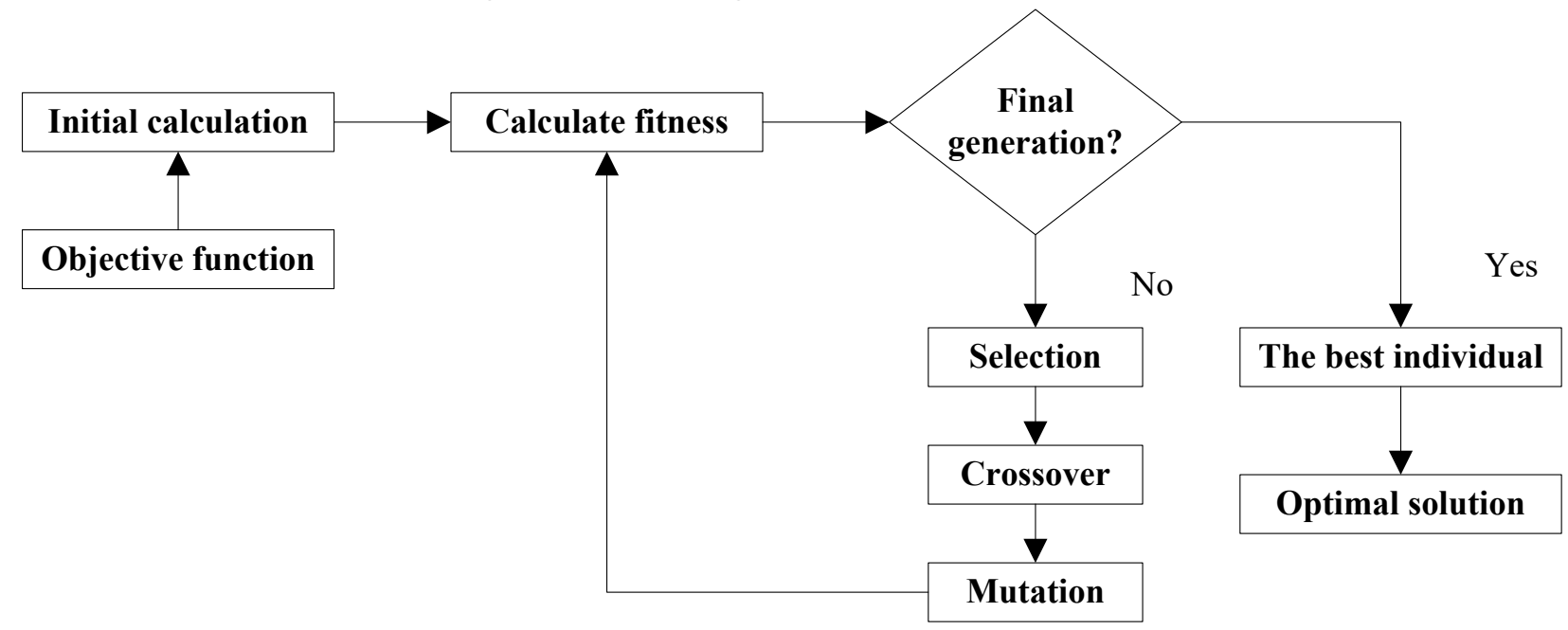

Figure 3: Block Diagram of Genetic Algorithm

In the application of Genetic Algorithm to check the optimization results will involve several operators are:

- Evolution Operator that involves the selection process in it.

- Genetic operators involving crossover and mutation operators.

The fitness function describes a solution of a problem that has been defined from the beginning. During walking, the parent must be used for reproduction, cross-over and mutation to create offspring.

DSS in joint with integrated, genetic algorithms can experience behavioral changes and adapt over time in order to provide improved decision support based on previous experience. In this sort of instance, various GA-based decision support systems are developed as a genetic algorithm is being integrated [8].

\subsection{Analytic Hierarchy Process (AHP)}

AHP method is one of the models for decision making that can help the framework of human thinking. This method was first developed by Thomas L. Saaty in the 70s. The basis of the AHP method is the numerical forming process to rank each decision alternative based on how it should be matched against the decision-making criteria. The structure of AHP hierarchy in this study can be seen in Figure 4. The steps of AHP method as follows:

- Determine the problem

- Arrange Hierarchy

- Prepare matrix pairwise comparison

- Assessing matrix pairwise comparison

- Synthesis matrix pairwise comparison

- Calculating global priority rankings

- Selection of the best alternative 


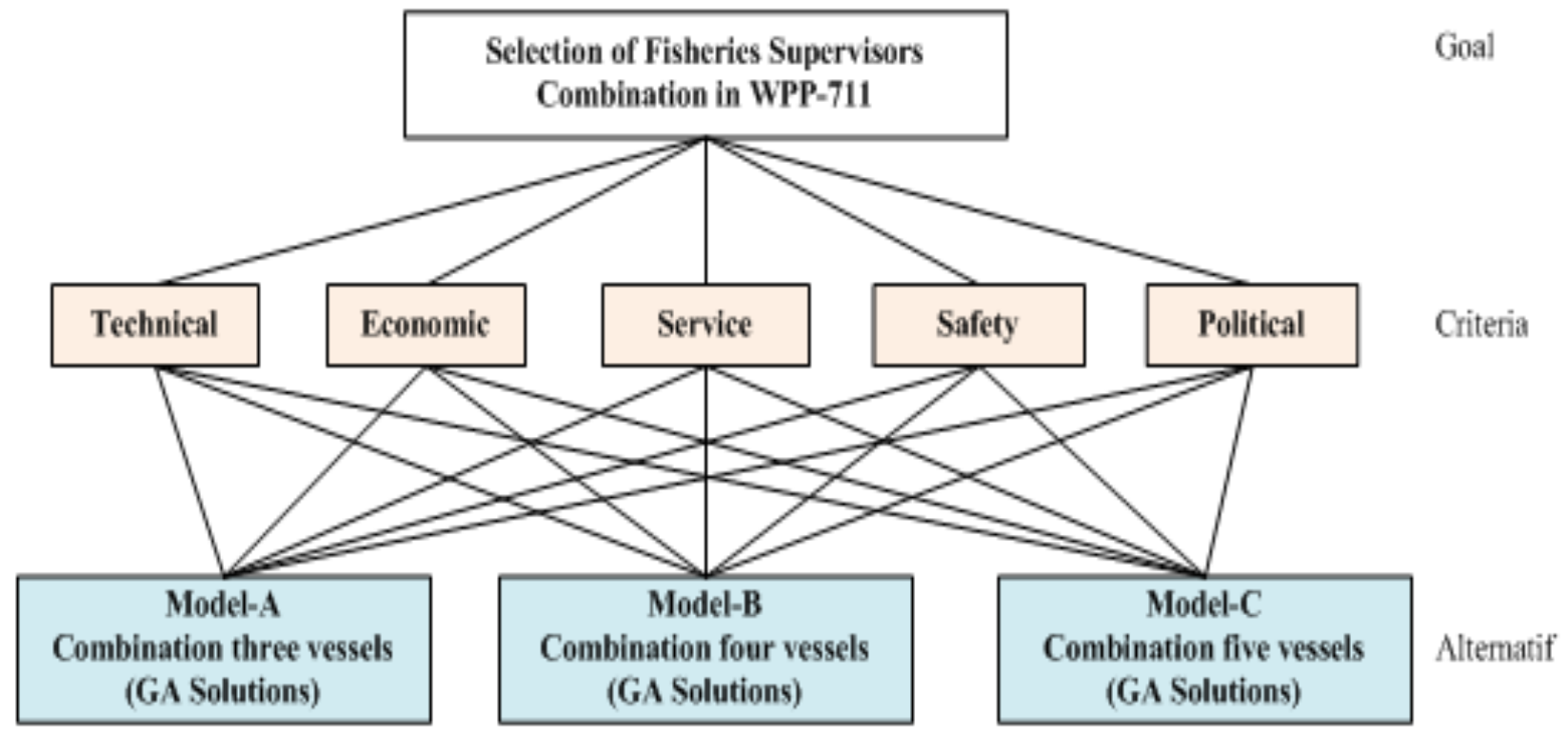

Figure 4: Structure of Hierarchy

Analytical Hierarchy Process (AHP) is an ideal method that can provide an alternative level or ranking when multiple criteria and sub-criteria are in the decision making process. Many studies use the AHP method to solve problems related to multi-criteria and complex [9]. AHP is used to assess the qualitative factors presented subjectively. This assessment is given by comparing the elements. The comparison is done by giving a score. Scoring used is a scale of 1-9.

\section{Result and Discussion}

This study aims to find the optimal combination of fisheries surveillance vessel assigned to each work unit in the Fisheries Management Area 711.

Table 1: Specification of fisheries surveillance vessel

\begin{tabular}{lcccccccc}
\hline No & Vessel type & Amount & $\begin{array}{c}\text { Length of } \\
\text { vessel (m) }\end{array}$ & $\begin{array}{c}\text { Speed } \\
\text { (Knot) }\end{array}$ & $\begin{array}{c}\text { Endurance } \\
\text { (day) }\end{array}$ & $\begin{array}{c}\text { Radar } \\
(\mathrm{NM})\end{array}$ & \multicolumn{2}{c}{$\begin{array}{c}\text { Vessel placement } \\
\text { Westren }\end{array}$} \\
\hline 1 & A & 4 & 60 & 25 & 8 & 64 & 2 & 2 \\
2 & B & 2 & 42 & 18 & 4 & 96 & 1 & 1 \\
3 & C & 7 & 36 & 24 & 3 & 48 & 4 & 3 \\
4 & D & 17 & 23 & 28 & 3 & 48 & 8 & 9 \\
5 & E & 5 & 18 & 15 & 3 & 48 & 3 & 2 \\
\hline
\end{tabular}


Table 2: Optimization results in Pontianak working unit

\begin{tabular}{lccccr}
\hline Work Unit & \multirow{2}{*}{ Number } & $\begin{array}{c}\text { Vessel } \\
\text { Type }\end{array}$ & $\begin{array}{c}\text { Coverage } \\
(\text { Mil) }\end{array}$ & $\begin{array}{c}\text { Cost Operation } \\
(\text { Rp) }\end{array}$ & Fitness \\
\hline \multirow{3}{*}{ Pontianak } & \multirow{2}{*}{2} & D-D & 61.316 & 523.934 .712 & 1.841 \\
& & C-D & 57.169 & 338.119 .284 & 2.363 \\
& \multirow{2}{*}{3} & B-E & 61.016 & 396.080 .169 & 2.235 \\
& E-C-E & 60.871 & 345.324 .412 & 2.401 \\
\hline
\end{tabular}

Table 3: Optimization results in Batam working unit

\begin{tabular}{cccccc}
\hline \multirow{2}{*}{ Work Unit } & \multirow{2}{*}{ Number } & $\begin{array}{c}\text { Vessel } \\
\text { Type }\end{array}$ & $\begin{array}{c}\text { Coverage } \\
\text { (Mil) }\end{array}$ & $\begin{array}{c}\text { Cost Operation } \\
\text { (Rp) }\end{array}$ & \multirow{2}{*}{ Fitness } \\
\hline \multirow{2}{*}{ Batam } & \multirow{2}{*}{2} & E-D & 47.838 & 170.090 .284 & 4.276 \\
& & D-E & 47.838 & 170.090 .284 & 4.276 \\
\hline
\end{tabular}

Fitness Coverage Area $(\mathrm{Ca})$ :

- Fitness $1 \geq 98.106 \mathrm{Mil}^{2}$ (Work Unit Natuna)

- Fitness $2 \geq 56.060 \mathrm{Mil}^{2}$ (Work Unit Pontianak)

- Fitness $_{3} \geq 46.050 \mathrm{Mil}^{2}$ (Work Unit Batam)

Fitness Operational Cost $(\mathrm{Oc})$ :

- Fitness $1 \geq 9.310 .106 .993$ IDR (Work Unit Natuna)

- Fitness $2 \geq 5.505 .373 .644$ IDR (Work Unit Pontianak)

- Fitness $_{3} \geq 4.540 .371 .030$ IDR (Work Unit Batam)

Genetic Algorithm (GA) is only able to provide candidate solution according to fitness value which has been assigned to work unit according to Table 2, 3 and 4. The optimization result using GA with 1000 iteration, population $=100$, probability crossover $=0.8$, mutation probability $=0.05$ in FMA711 can be shown in tables 2, 3 and 4 .

The optimization result using GA method for work unit in pontianak and batam result tends toward one solution, but for work unit in Natuna tend to have more variation. therefore, it is necessary to consider the decision maker with several criteria, namely:

1. Technical (T);

2. Economic (E);

3. Service (SE);

4. Safety (SA).

5. Politics $(\mathrm{P})$

Alternative decisions that will be assessed based on criteria: technical, economic, service, safety and politics as shown in Table 2 . The decision hierarchy to assess some alternative candidate solutions in the natuna work unit is shown in Fig. 4.

Selecting several alternative decisions from the results of genetic algorithm optimization according to Table 2 is difficult work because of many interests and considerations. Therefore, by analyzing the calculation of importance level on each criteria and alternative will get best solution from good using the Saaty scale. 
Table 5: Rating Scale Saaty [9]

\begin{tabular}{|c|l|}
\hline Numerical Scale & \multicolumn{1}{c|}{ Verbal Scale } \\
\hline 1 & Equally importance \\
\hline $2,4,6,8$ & Intermediate value \\
\hline 3 & Moderate importance \\
\hline 5 & Strong importance \\
\hline 7 & Very strong importance \\
\hline 9 & Extreme importance \\
\hline
\end{tabular}

Furthermore, forming matrix pairwise comparison criteria, as well as doing a comparative assessment of the criteria.

Table 6. Criteria calculation

\begin{tabular}{cccccc}
\hline Criteria & Technical & Economic & Service & Safety & Politics \\
\hline Technical & 1.000 & 3.000 & 5.000 & 6.000 & 6.000 \\
Economic & 0.333 & 1.000 & 3.000 & 4.000 & 4.000 \\
Service & 0.200 & 0.333 & 1.000 & 2.000 & 2.000 \\
Safety & 0.167 & 0.250 & 0.500 & 1.000 & 1.000 \\
Politics & 0.167 & 0.250 & 0.500 & 1.000 & 1.000 \\
\hline Amount & $\mathbf{1 . 8 6 7}$ & $\mathbf{4 . 8 3 3}$ & $\mathbf{1 0 . 0 0 0}$ & $\mathbf{1 4 . 0 0 0}$ & $\mathbf{1 4 . 0 0 0}$ \\
\hline
\end{tabular}

Next change the normalization matrix pairwise comparison.

Table 7. Criteria normalization values

\begin{tabular}{cccccccc}
\hline Criteria & Technical & Economic & Service & Safety & Politics & $\begin{array}{c}\text { Number } \\
\text { of rows }\end{array}$ & $\begin{array}{c}\text { Vector } \\
\text { Eigen }\end{array}$ \\
\hline Technical & 0.536 & 0.621 & 0.500 & 0.429 & 0.429 & 2.514 & 0.503 \\
Economic & 0.179 & 0.207 & 0.300 & 0.286 & 0.286 & 1.257 & 0.251 \\
Service & 0.107 & 0.069 & 0.100 & 0.143 & 0.143 & 0.562 & 0.112 \\
Safety & 0.089 & 0.052 & 0.050 & 0.071 & 0.071 & 0.334 & 0.067 \\
Politics & 0.089 & 0.052 & 0.050 & 0.071 & 0.071 & 0.334 & 0.067 \\
\hline
\end{tabular}

Table 8. Consistency ratio of criteria comparison

\begin{tabular}{|c|c|c|c|c|c|c|}
\hline Technical & Economic & Service & Safety & Politics & Amount & $\begin{array}{c}\text { Lamda } \\
\text { Max }\end{array}$ \\
\hline 0.503 & 0.754 & 0.562 & 0.401 & 0.401 & 2.620 & 5.212 \\
\hline 0.168 & 0.251 & 0.337 & 0.267 & 0.267 & 1.290 & 5.133 \\
\hline 0.101 & 0.084 & 0.112 & 0.134 & 0.134 & 0.564 & 5.018 \\
\hline 0.084 & 0.063 & 0.056 & 0.067 & 0.067 & 0.336 & 5.037 \\
\hline 0.084 & 0.063 & 0.056 & 0.067 & 0.067 & 0.336 & 5.037 \\
\hline
\end{tabular}


Based on calculations that have been done where the CR value for the criteria factor used shows a value smaller than 0.1 , it can be concluded that the pairwise comparison is done consistently as in Table 8.

After calculation of comparison between criteria, obtained eigen value of Politics $=0.050$, Safety $=0.122$, Service $=0.094$, Economic $=0.318$ and Technical $=0.417$ so obtained matrix results in table 7.

Based on the Eigen value, the order of importance for each criterion in the selection of combination of fishing vessel in each work unit is: [1] technical $=0.417$, [2] economic $=0.318$, [3] safety $=0.122$, [4] service $=0.094$ and [5] political $=0.050$.

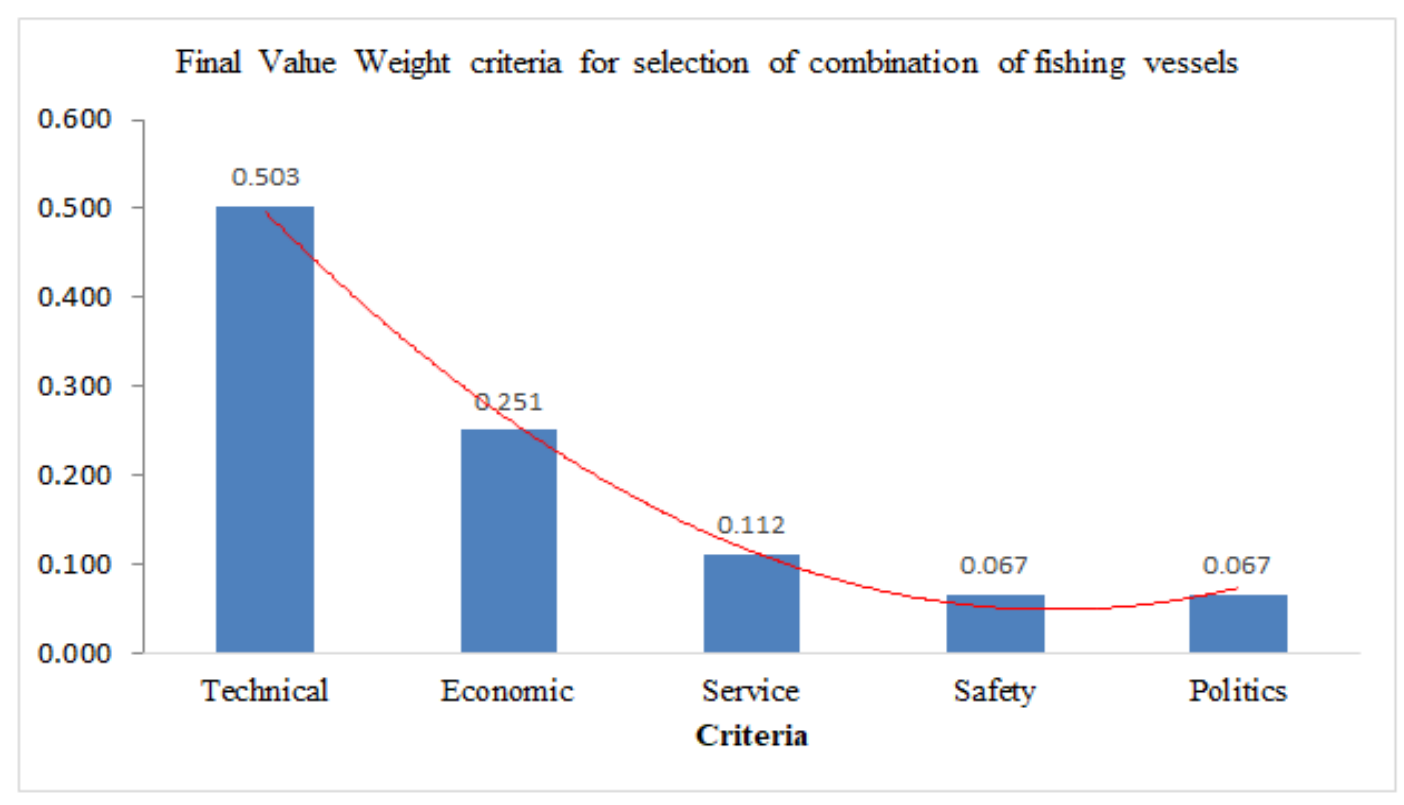

Figure 5: Results of ranking criteria

This means that the Government in choosing a supervisory ship to be placed to each work unit is more concerned with technical, economic and safety considerations. So the ships selected to secure FMA-711 are likely to ship with high technology, low operational cost and good reliability/security.

Based on the consideration of the interest of decision makers in each criterion, the final result of weight value on each alternative (combination of fishing vessel) in each of the main work units of WPP-711 is as follows:

\subsection{Combination solution of fishing vessel in Natuna main working area}

The final value of the weight of the alternative assessment of Natuna main working unit compared with each predefined criterion, obtained the following results: 
Table 9. Final value by AHP method for tree combination of fishing vessels in Natuna

\begin{tabular}{|c|c|c|c|c|}
\hline $\begin{array}{l}\text { Combination of } \\
\text { Fishing Vessel }\end{array}$ & Criteria & $\begin{array}{l}\text { Weighting } \\
\text { Criteria }\end{array}$ & $\begin{array}{c}\text { Alternative } \\
\text { Weight }\end{array}$ & $\begin{array}{l}\text { Final } \\
\text { Score } \\
\end{array}$ \\
\hline \multirow{5}{*}{ B-A-C } & Technical & 0.503 & 0.333 & 0.167 \\
\hline & Economic & 0.251 & 0.032 & 0.008 \\
\hline & Service & 0.112 & 0.041 & 0.005 \\
\hline & Safety & 0.067 & 0.351 & 0.023 \\
\hline & Politic & 0.067 & 0.360 & 0.024 \\
\hline \multirow{6}{*}{ B-D-D } & & & Total & 0.0227 \\
\hline & Technical & 0.503 & 0.200 & 0.100 \\
\hline & Economic & 0.251 & 0.277 & 0.070 \\
\hline & Service & 0.112 & 0.193 & 0.022 \\
\hline & Safety & 0.067 & 0.130 & 0.009 \\
\hline & Politic & 0.067 & 0.170 & 0.011 \\
\hline \multirow{6}{*}{ B-D-C } & & & Total & 0.212 \\
\hline & Technical & 0.503 & 0.226 & 0.114 \\
\hline & Economic & 0.251 & 0.255 & 0.064 \\
\hline & Service & 0.112 & 0.280 & 0.031 \\
\hline & Safety & 0.067 & 0.186 & 0.012 \\
\hline & Politic & 0.067 & 0.179 & 0.012 \\
\hline \multirow{6}{*}{ B-C-C } & & & Total & 0.234 \\
\hline & Technical & 0.503 & 0.047 & 0.024 \\
\hline & Economic & 0.251 & 0.151 & 0.038 \\
\hline & Service & 0.112 & 0.178 & 0.020 \\
\hline & Safety & 0.067 & 0.109 & 0.007 \\
\hline & Politic & 0.067 & 0.093 & 0.006 \\
\hline \multirow{6}{*}{ B-E-B } & & & Total & 0.095 \\
\hline & Technical & 0.503 & 0.125 & 0.063 \\
\hline & Economic & 0.251 & 0.129 & 0.063 \\
\hline & Service & 0.112 & 0.129 & 0.015 \\
\hline & Safety & 0.067 & 0.084 & 0.006 \\
\hline & Politic & 0.067 & 0.079 & 0.005 \\
\hline \multirow{7}{*}{ A-D-D } & & & Total & 0.121 \\
\hline & Technical & 0.503 & 0.035 & 0.017 \\
\hline & Economic & 0.251 & 0.078 & 0.020 \\
\hline & Service & 0.112 & 0.088 & 0.01 \\
\hline & Safety & 0.067 & 0.061 & 0.004 \\
\hline & Politic & 0.067 & 0.056 & 0.004 \\
\hline & & & Total & 0.055 \\
\hline \multirow{5}{*}{ A-B-E } & Technical & 0.503 & 0.035 & 0.017 \\
\hline & Economic & 0.251 & 0.078 & 0.02 \\
\hline & Service & 0.112 & 0.087 & 0.01 \\
\hline & Safety & 0.067 & 0.079 & 0.005 \\
\hline & Politic & 0.067 & 0.063 & 0.004 \\
\hline & & & Total & 0.056 \\
\hline
\end{tabular}


The results of the calculation of each criterion for the criteria and alternatives combination of three fishing vessels in the Natuna work unit, the final value of ranking as shown in table 10.

Table 10. Final weight tree combination of fishing vessel in work unit Natuna

\begin{tabular}{ccc}
\hline Rank & $\begin{array}{c}\text { Combination of } \\
\text { Fishing Vess els }\end{array}$ & $\begin{array}{c}\text { Final } \\
\text { Weight }\end{array}$ \\
\hline 2 & B-A-C & 0.227 \\
3 & B-D-D & 0.212 \\
1 & B-D-C & 0.234 \\
5 & B-C-C & 0.095 \\
4 & B-E-B & 0.121 \\
7 & A-D-D & 0.055 \\
6 & A-B-E & 0.056 \\
\hline
\end{tabular}

Table 10 illustrates that the percent value of the best selection of the best combination of fishing vessels based on the technical, economic, service, safety and political criteria approach $\mathrm{BAC}=0.227$, $\mathrm{BDD}=0.212, \mathrm{BDC}=0.234, \mathrm{BCC}=0.095, \mathrm{BEB}=0.121, \mathrm{ADD}=0.055$ and $\mathrm{ABE}=0.056$. This means that decision makers prefer combinations of type $\mathrm{B}, \mathrm{D}$ and $\mathrm{C}$ vessels to secure the Natuna working unit area with coverage coverage area $=101.005 \mathrm{Mil} 2$ and operational cost IDR. 675.100.982 as shown in figure 6 .

The difference in weight between the combination of fishing vessels BDC and BAC is only $0.6 \%$, the basic consideration is the selection of Type A and D vessels, technically the combination of BAC is always selected, but the operational cost considerations of the combination of vessels are not elected due to decision makers already considering the achievement of ship type coverage BDC has been able to secure the Natuna unit area optimally.

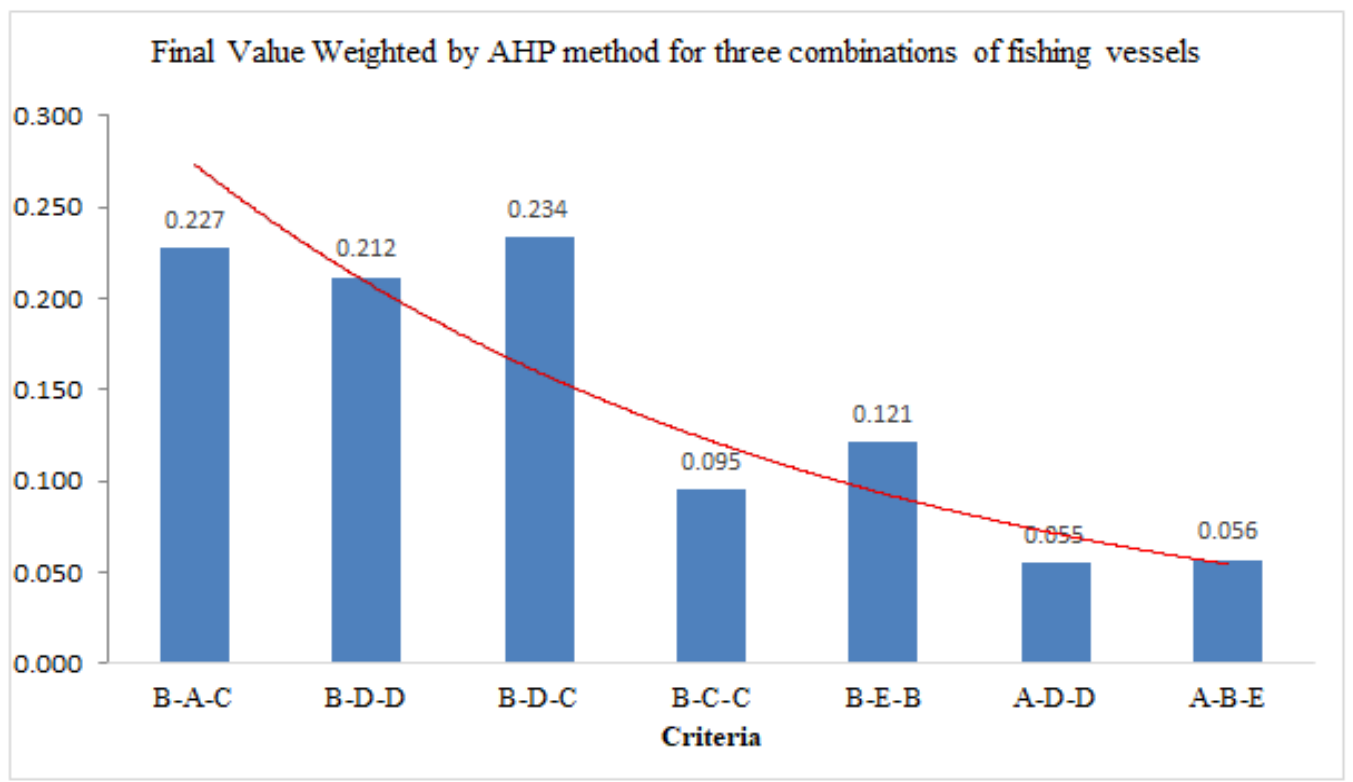

Figure 6: Final value by AHP method for tree combination of fishing vessels in Natuna 


\subsection{Combination solution of fishing vessel in Pontianak main working area}

The final value of the weight of the alternative appraisal in the Pontianak work unit is compared to each of the predefined criteria with the following results:

Table 11. Final value by AHP method for two and tree combination of fishing vessels in Pontianak

\begin{tabular}{ccccc}
\hline $\begin{array}{c}\text { Combination of } \\
\text { Fishing Vessels }\end{array}$ & Criteria & $\begin{array}{c}\text { Weighting } \\
\text { Criteria }\end{array}$ & $\begin{array}{c}\text { Alternative } \\
\text { Weight }\end{array}$ & $\begin{array}{c}\text { Final } \\
\text { Score }\end{array}$ \\
\hline \multirow{4}{*}{ D-D } & Technical & 0.503 & 0.124 & 0.062 \\
& Economic & 0.251 & 0.068 & 0.017 \\
& Service & 0.112 & 0.387 & 0.044 \\
& Safety & 0.067 & 0.176 & 0.012 \\
& Politic & 0.067 & 0.329 & 0.022 \\
\hline & & & Total & $\mathbf{0 . 1 5 7}$ \\
\hline \multirow{4}{*}{ C-D } & Technical & 0.503 & 0.124 & 0.062 \\
& Economic & 0.251 & 0.152 & 0.038 \\
& Service & 0.112 & 0.275 & 0.031 \\
& Safety & 0.067 & 0.253 & 0.017 \\
& Politic & 0.067 & 0.329 & 0.022 \\
\hline \multirow{4}{*}{ B-E } & & & Total & $\mathbf{0 . 1 7 0}$ \\
\hline & Technical & 0.503 & 0.439 & 0.221 \\
& Economic & 0.251 & 0.456 & 0.115 \\
& Service & 0.112 & 0.198 & 0.022 \\
& Safety & 0.067 & 0.319 & 0.021 \\
& Politic & 0.067 & 0.200 & 0.013 \\
\hline & & & Total & $\mathbf{0 . 3 9 2}$ \\
\hline \multirow{6}{*}{ E-C-E } & Technical & 0.503 & 0.313 & 0.158 \\
& Economic & 0.251 & 0.324 & 0.081 \\
& Service & 0.112 & 0.140 & 0.016 \\
& Safety & 0.067 & 0.252 & 0.017 \\
& Politic & 0.067 & 0.142 & 0.009 \\
\hline & & & Total & $\mathbf{0 . 2 8 1}$ \\
& & & &
\end{tabular}

The result of the calculation of each criterion for alternative combinations of two and three fishing vessels in the Pontianak work unit obtained the final value of ranking as shown in table 12.

Table 12. Final weight tree combination of fishing vessel in work unit Pontianak

\begin{tabular}{ccc}
\hline Rank & $\begin{array}{c}\text { Combination of } \\
\text { Fishing Ves sels }\end{array}$ & $\begin{array}{c}\text { Final } \\
\text { Weight }\end{array}$ \\
\hline 2 & D-D & 0.157 \\
3 & C-D & 0.170 \\
1 & B-E & 0.392 \\
4 & E-C-E & 0.281
\end{tabular}

Based on table 12 it is found that the best percentage of selection of the best combination of fishing vessels based on the \{technical, economical, service, safety and political criteria\} approach is obtained $(\mathrm{DD}=16 \%),(\mathrm{CD}=17 \%),(\mathrm{BE}=39 \%)$ and $(\mathrm{ECE}=28 \%)$. This means that the decision 
makers prefer combination of type B and E ships to secure the work area of Pontianak with coverage area coverage $=61.016 \mathrm{Mil} 2$ and operational cost IDR. 396.080.169 as shown in fig. 7 .

The difference between the combinations of [BE] and [ECE] is only $11 \%$, the basic consideration is the selection of $B$ and $C$ type ships, technically a combination of [BE] is always selected and consideration of the combined operating costs of the vessel is also selected because decision makers have considered the achievement of coverage ship type [BE] area has been able to secure the Pontianak working unit area well and the cost is lower.

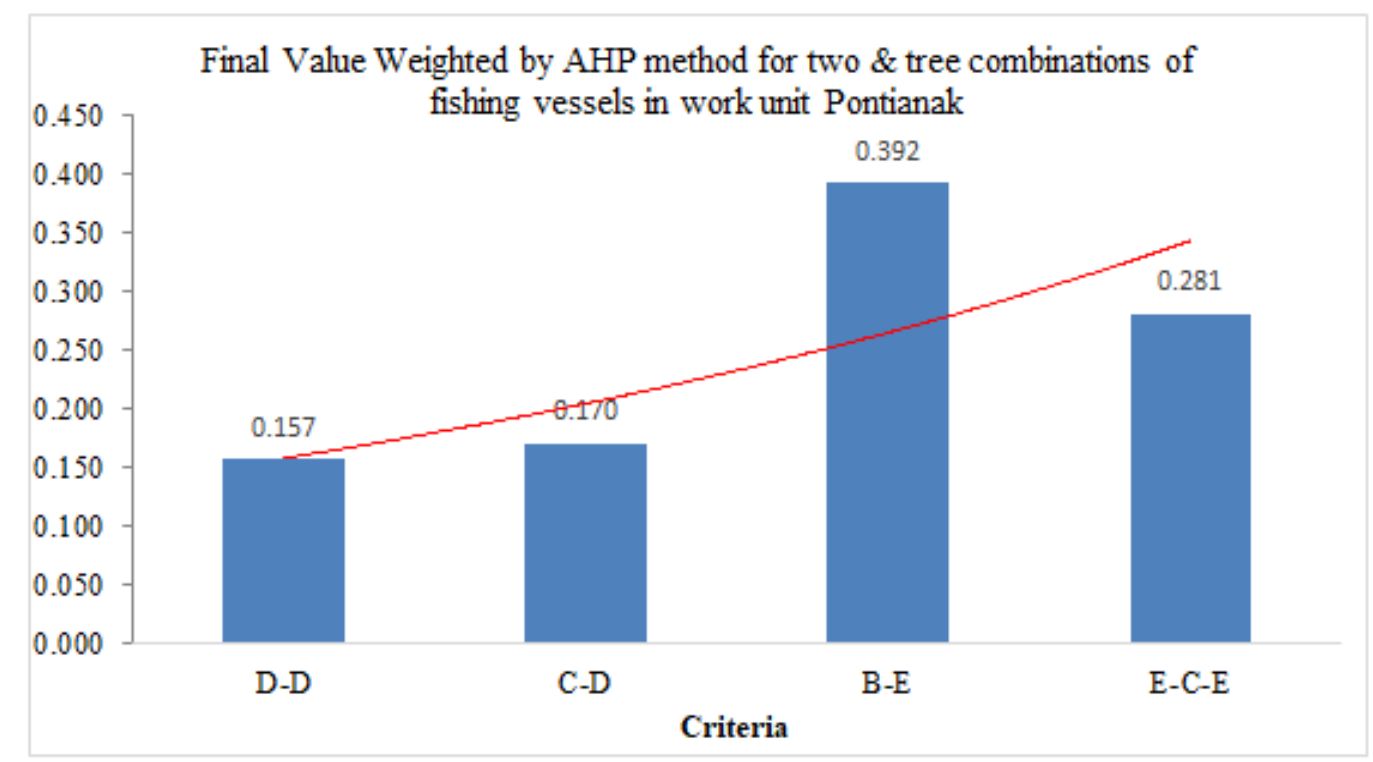

Figure 7: Final value by AHP method for tree combination of fishing vessels in Natuna

\subsection{Combination solution of fishing vessel in Batam main working area}

Based on optimization result for Batam work unit, one of the most optimal solution is the combination of ship type [E-D] as shown in table 4. So there is no need for comparison process of interest with consideration of criterion (technical, economical, service, safety and politic).

Genetic Algorithm is the most suitable method to solve complex problems with large amount of data variation, so to solve the problem of choosing the best combination of ship in Batam work unit do not experience difficulties because the number of data variance presented is simple that small work unit area of Batam and limited variety of fishing vessels.

\section{Conclusion}

The main objective of this study was to determine the combination of fisheries surveillance vessel in the main work unit in the fisheries supervision area 711. This research has found the best solution of fishing vessel in Natuna working unit with combination of type B-D-C, Pontianak work unit with combination of type B-E and Batam work unit with combination of type E-D. The results of this study support the policy of the Government of the Republic of Indonesia to optimize the protection of the Indonesian sea, especially in the area of fishery surveillance 711 . This research contributes greatly to the development of the Indonesian marine surveillance model and it is also important that this research contribute to the development of intelligent decision support systems by combining Genetic Algorithm (GA) and Analytic Hierarchy Process (AHP) methods. The limitations of this study in the optimization model do not take into account the age variables of the ship, the level of vulnerability, 
the weather in each region and the prediction of violations in each work unit. Although the optimization model variables are limited, this study has provided very important inputs for the Government to improve fishery control performance throughout Indonesia as it will be able to save the operational cost of the vessel and maximize the cruising range of supervisory vessels. This research should be repeated using different optimization variables, a combination of intelligent decision support system methods (NSGA and Fuzzy AHP or NSGA and ANP) results from this combination of methods need to be tested multiple times with different data samples, if by model the results are good, then the model can be thrown into the application software.

\section{References}

[1] S. Abdurrahman, Book of Data and Information on Marine Resource and Fishery Monitoring. 2013.

[2] R. Noviyanti, "Fishery Condition In The Fishery Management (WPP) Indonesia," no. 1. pp. 1-6, 2011.

[3] Y. Krisnafi, B. H. Iskandar, and S. H. Wisudo, "Optimization of fisheries surveillance vessel deployment in Indonesia using genetic algorithm (Case study: Fisheries Management Area 711, ” AACL Bioflux, vol. 10, no. 3, pp. 565-577, 2017.

[4] H. L. Hozairi, Yaser K, "Sistem Pendukung Keputusan Penentuan Prioritas Wilayah Pengawasan Perikanan (WPP711) Menggunakan Metode AHP-TOPSIS, ” in Seminar Nasional Ilmu Terapan (SNITER), 2017, vol. 3, pp. 1-7.

[5] J. H. Yaser Krisnafi, Hozairi, Budhi Hascaryo Iskandar, Sugeng Hari Wisudo, "Decision Support System Determination of Main Work Unit in WPP-711 using Fuzzy TOPSIS, ” Knowledge Enggineering and Data Science (KEDS), vol. 1, no. 1, pp. 8-19, 2018.

[6] M. F. Aly and H. M. A. El-hameed, "Integrating AHP and Genetic Algorithm Model Adopted for Personal Selection," International Journal of Enggineering Trends and Technology (IJETT), vol. 6, no. 5, pp. 247-256, 2013.

[7] T. Pati, S. Barat, D. I. Komputer, D. Teknologi, and I. Pertanian, "Intelligent Decision Support System For Natural Rubber Agroindustry Development With Green Productivity Approach Using Fuzzy AHP," Jurnal Teknologi Industri Pertanian, vol. 24, no. 2, pp. 82-96, 2014.

[8] I. Sbeity, M. Dbouk, and H. Kobeissi, "Combining The Analytical Hierarchy Process and The Genetic Algorithm to Solve theTimetable Problem," International Journal of Software Engineering \& Applications (IJSEA), vol. 5, no. 4, pp. 39-50, 2014.

[9] T. L. Saaty, "Decision making with the analytic hierarchy process," Int.J.Services Sciences, vol. 1, no. 1, 2008.

[10] Intelligent Decision Support Systems. 2015.

[11] A. A. Masroeri, "Intelligent Decision Support Systems (IDSS) For Multi-Objective Optimization Problems At Sea Security Indonesia, ” Journal of Theoretical and Applied Information Technology, vol. 81, no. 1, pp. 108-115, 2015.

[12] Q. Zhou, G. H. Huang, and C. W. Chan, "Development of an intelligent decision support system for air pollution control at coal-fired power plants," Expert Systems With Applications, vol. 26, pp. 335-356, 2004.

[13] A. Quintero, D. Konar, and S. Pierre, "Prototyping an intelligent decision support system for improving urban infrastructures management," European Journal of Operational Research, vol. 162, pp. 654-672, 2005. 